\title{
A Study on the Stability and Sludge Energy Efficiency Evaluation of Torrefied Wood Flour Natural Material Based Coagulant ${ }^{1}$
}

\author{
Hae Keum $\mathrm{PARK}^{2} \cdot$ Seog Goo KANG ${ }^{2, \dagger}$
}

\begin{abstract}
Sewage treatment plants are social infrastructure of cities. The sewage distribution rate in Korea is reaching $94 \%$ based on the sewage statistics based in the year of 2017. In Korean sewage treatment plants, use of PAC (Poly Aluminum Chloride) accounts for $58 \%$. It contains a large amount of impurities (heavy metal) according to the quality standards, however, there have been insufficient efforts to reinforce the standards or technically improve the quality, which resulted in secondary pollution problems from injecting excessive coagulant. Also, the increase in the use of chemicals is leading to the increases in the annual amount of sewage sludge generated in 2017 and the need to reuse sludge. As such, this study aims to verify the possibility of reusing sludge by evaluating the stability of heavy metals based on the injection of coagulant mixture during water treatment which uses the torrefield wood powder and natural materials, and evaluating the sedimentation and heating value of sewage sludge. As a result of analyzing heavy metals $(\mathrm{Cr}$, $\mathrm{Fe}$, $\mathrm{Zn}, \mathrm{Cu}, \mathrm{Cd}, \mathrm{As}, \mathrm{Pb}$, and $\mathrm{Ni}$ ) from the coagulant mixture and $\mathrm{PAC}(10 \%), \mathrm{Cr}, \mathrm{Cd}, \mathrm{Pb}, \mathrm{Ni}$, and $\mathrm{Hg}$ were not detected. As for $\mathrm{Zn}$, while its concentration notified in the quality standards for drinking water is $3 \mathrm{mg} / \mathrm{L}$, only a small amount of $0.007 \mathrm{mg} / \mathrm{L}$ was detected in the coagulant mixture. Maximum amounts of over double amounts of $\mathrm{Fe}, \mathrm{Cu}$, and As were found with PAC (10\%) compared to the coagulant mixture. Also, an analysis of sludge sedimentation found that the coagulant mixture showed a better performance of up to double the speed of the conventional coagulant, PAC $(10 \%)$. The dry-basis lower heating value of sewage sludge produced by injecting the coagulant mixture was 3,378 $\mathrm{kcal} / \mathrm{kg}$, while that of sewage sludge generated due to PAC (10\%) was $3,171 \mathrm{kcal} / \mathrm{kg}$; although both coagulants met the requirements to be used as auxiliary fuel at thermal power plants, the coagulant mixture developed in this study could secure heating values $200 \mathrm{kal} / \mathrm{kg}$ higher than the counterpart. Therefore, utilization of the coagulant mixture for water treatment rather than PAC $(10 \%)$ is expected to be more environmentally stable and effective, as it helps generating sludge with better stability against heavy metals, having a faster sludge sedimentation, and higher heating value.
\end{abstract}

Keywords: positively charged torrefied wood flour, heavy metals stability, sludge heat value

\section{INTRODUCTION}

Sewage treatment plants are social infrastructure built in cities as a result of economic development and urbanization. Based on the 2017 sewage statistics, the sewage distribution rate in Korea is $94 \%$, and the number of the sewage treatment plants is reaching 4,072. Due to global warming and extreme weather

\footnotetext{
${ }^{1}$ Date Received September 6, 2019, Date Accepted March 9, 2020

2 Department of Biobased Materials, College of Agriculture and Life Science, Chungnam National University, Deajeon 34134, Republic of Korea

† Corresponding author: Seog Goo KANG (e-mail: lachesis@cnu.ac.kr, ORCID: 0000-0002-2440-7070)
} 
phenomenon caused by economic growth, the increased importance of water quality management is resulting in the increase in the management costs every year (Hwang and Choi, 2018). Korean sewage treatment plants introduced advanced treatment facilities, reinforced the criteria for discharged water quality, and implemented the Total Water Pollution Load Management System for a stable water quality improvement. With the improvement of sewer lines from the combined pipe type to the separated type, the amount of sewage inflow decreased. However, the actual amount of chemical use is increasing due to the increase in the pollutant load (MOE, 2017). As for coagulant used in Korean sewage treatment plants, the use of inorganic polymer coagulant, PAC (Poly Aluminum Chloride), accounts for $58 \%$. Although it contains a large content of impurities (heavy metal) according to the quality standards, there have been insufficient efforts for reinforcing the standards or technically improving the quality, which led to secondary pollution problems from an excessive coagulant injection (Park, 2009). With the increase in the use of chemicals, the annual amount of sludge generated in sewage is $11,415 \mathrm{~m}^{3} / \mathrm{d}$ as of 2017, which has been increasing (So et al., 2018). Accordingly, additional solutions for reusing the sewage sludge are being explored, and the reuse rate has also increased by recycling sludge as auxiliary fuel and fertilizer.

However, as dumping sewage sludge in the ocean is now completely prohibited under the London Convention, sewage sludge is finally disposed of through landfill, recycling, and pretreatment on land (Han et al., 2019). Also, landfill treatment is limited since landfilling sewage sludge has been prohibited under the Wastes Control Act recently. For this reason, new solutions for an efficient treatment of sewage sludge are demanded. Accordingly, the necessity for sewage sludge reduction or effective sludge-to-resource and sludge-toenergy using various pretreatment technologies is being raised (Choi et al., 2016). In order to increase the recycling rate of sewage sludge, the sewage sludge is currently being used as auxiliary fuel at thermal power plants through thermal treatment processes including drying, incineration, and carbonization; sludge-to-compost; fertilizer through the aging process; green soil and cover materials; and auxiliary materials for cement production (Yeon et al., 2016). In the case of sludge-tocompost, however, the processing time is too long that it requires too much land, equipment capacity, and high cost. Meanwhile, an environmental safety issue is being raised for the heavy metals included in sludge for the case of using it as fertilizer (Lee, 2004).

In addition to water pollution problems caused by global warming, the forest environment is also facing problems due to the inflow and spread of disease and pests. Although various preventive measures and plans have been developed for trees damaged by disease and pests, such as fumigation and incineration, lack of clear treatment methods had resulted in economic loss of forest resources. As such, it is necessary to find a solution to expand the use of domestic forest resources by applying high-value-adding technology to unused forest resources such as trees damaged by disease and pests and the by-products of forestry processes, etc. (Lee et al., 2015) Accordingly, research on torrefaction for various types of biomass such as the analysis of antioxidants from extracts using torrefied wood powder, farming byproducts, and sewage sludge is in progress (Nam et al., 2018; Gong et al., 2016). In this study, coagulant mixture of torrefied wood powder and natural materials is used for water treatment to evaluate the stability against heavy metals by comparing and analyzing the heavy metal contents after injecting the coagulant mixture and PAC. In addition, the sedimentation and heating values of sludge produced in the processes of mixing and coagulation after injecting the coagulants at a sewage treatment plant are investigated to verify the environmental stability of sludge and its 
A Study on the Stability and Sludge Energy Efficiency Evaluation of

Torrefied Wood Flour Natural Material Based Coagulant

potential of reuse as auxiliary fuel at thermal power plants.

\section{MATERIALS and METHODS}

\subsection{Preparation of coagulant mixture of torrefied wood powder and natural materials}

In the preparation of coagulant mixture of torrefied wood powder and natural materials, this study selected the same condition withthat of the preparation of torrefied wood pellets in the previous research (Yang et al., 2016), which revealed that torrefied wood powder controls negative charges and adsorbs liquid according to the superheated steam treatment conditions. To make torrefied wood pellets, oak wood pellets with a water content of $12 \%$ were used. The researcher had commissioned Company S located in Gumi to have torrefied wood pellets treated at $250{ }^{\circ} \mathrm{C}$ for 25 minutes using a superheated steam treatment system. The pellets were then crushed witha laboratory high-speed pulverizer and sorted to a size of 75-106 um (Yang et al., 2017). In preparing the coagulant mixture, an inorganic polymer coagulant of PAC was used. The inorganic polymer compound with a structure of basic polynuclear complexes with cationic charges is strong coagulant for water treatment. PAC is a polymer-based coagulant made of hydrochloric acid and aluminum. In this study, colorless or pale yellow transparent liquid-type PAC was used. For PAC commonly used in Korean sewage treatment plants $(10 \%)$, the concentration of aluminum oxide $\left(\mathrm{Al}_{2} \mathrm{O}_{3}\right)$ is $10 \%$. In this study, the concentration was reduced to $7 \%$ to produce PAC (7\%). Finally, the test material for this experiment was made by adding $5 \mathrm{~g}$ of torrefied wood powder to $500 \mathrm{ml}$ of PAC (7\%), which was prepared according to the mixing ratio developed in the research on the optimal mixing ratio of coagulant mixture of torrefied wood powderand natural materials (Yang et al., 2019) and then stirring at $800 \mathrm{rpm}$ for approximately 5 hours.

\subsection{Jar test}

To evaluate the stability, sludge sedimentation rate, and sludge heating value of the coagulant mixture, effluent from the primary sedimentation tank of Daejeon Sewage Treatment Plant, having a high organic content in water, was collected. A jar test was performed to examine the stability of the coagulant mixture according to its conditions; supernatants were collected with the operation conditions of $140 \mathrm{rpm} 2$ min for rapid mixing, $40 \mathrm{rpm} 20 \mathrm{~min}$ for slow mixing, and $30 \mathrm{~min}$ for settling. When collecting the supernatants, they were filtered through a syringe filter having $45 \mu \mathrm{m}$ pores. Analysis items included $\mathrm{Cr}, \mathrm{Fe}, \mathrm{Zn}$, $\mathrm{Cu}, \mathrm{Cd}, \mathrm{As}, \mathrm{Pb}, \mathrm{Ni}$, and $\mathrm{Hg}$, which are in the heavy metal category of "The Criteria For Water Quality Assessment (No. 2017-4)", and the sedimentation rate and heating value of sludge generated after the jar test were analyzed.

\subsection{The analysis of heavy metals}

In order to analyze the stability of the coagulant mixture prepared in this study, an analysis of heavy metals including $\mathrm{Cr}, \mathrm{Fe}, \mathrm{Zn}, \mathrm{Cu}, \mathrm{Cd}, \mathrm{As}, \mathrm{Pb}, \mathrm{Ni}$, and $\mathrm{Hg}$, which are subject to "The Criteria For Water Quality Assessment (No. 2017-4)”, was performed. The analysis was commissioned to FITI Testing \& Research Institute for sample analysis where spectrophotometry, luminescence spectroscopy, and mass spectrometry instrument analysis were performed three times.

\subsection{The analysis of sludge sedimentation}

In the experiment of the sedimentation of sludge generated in the sedimentation process through the mixing and coagulation processes of aquatic contaminants 
using the coagulant mixture, the sedimentation volume of flocs was measured for a certain period of time - every 1-10 min for $30 \mathrm{~min} \mathrm{-} \mathrm{using} \mathrm{a} \mathrm{measuring}$ cylinder. The flocs generated after the jar test were moved to a $1,000 \mathrm{ml}$ measuring cylinder so that they do not break. For the comparison and analysis of sludge sedimentation with the existing water treatment agent, the sludge sedimentation of the coagulant mixture prepared in this study and PAC (10\%) was compared based on the optimal injection amount.

\subsection{The analysis of sludge heating values}

To reuse sewage sludge as auxiliary fuel, it must satisfy the requirement of auxiliary fuel at thermal power plants: over 3,000 kcal $/ \mathrm{kg}$. To measure the heating value of sewage sludge, sludge settled after the Jar test was collected and dried in a drying oven at $105{ }^{\circ} \mathrm{C}$ to achieve water content of $10 \%$ or lower. For the measurement of the higher heating value, which is the criteria for absolute dry specimen, the value $(\mathrm{kcal} / \mathrm{kg})$ was measured five times using the Bomb Calorimeter (SDC series Calorimeter, YEONJIN S-TECH INC.), and then the lower heating value was calculated.

\section{RESULTS and DISCUSSION}

\subsection{The results of the analysis of heavy metals}

A jar test was conducted using effluent from the primary sedimentation tank at the DJ sewage treatment plant. After injecting $10 \mathrm{ml} / \mathrm{L}$ of each coagulant, which is the optimal amount based on the previous research, supernatants were collected, and then heavy metals $(\mathrm{Cr}$, $\mathrm{Fe}, \mathrm{Zn}, \mathrm{Cu}, \mathrm{Cd}, \mathrm{As}, \mathrm{Pb}$, and $\mathrm{Ni}$ ) were analyzed. The results are shown in Fig. 1.

As a result of mixing, coagulation, and sedimentation processes using the same amount of PAC (10\%) and the coagulant mixture, metals such as $\mathrm{Cr}, \mathrm{Cd}, \mathrm{Pb}$, $\mathrm{Ni}$, and $\mathrm{Hg}$ were not detected. It was alsofound that higher concentrations of $\mathrm{Fe}, \mathrm{Cu}$, and As were appeared in the water treated with PAC $(10 \%)$ coagulation. The post-test results for Fe with different types of treatment agents showed that the average of the coagulant mixture was $0.3143 \mathrm{mg} / \mathrm{L}$, while that of PAC $(10 \%)$ was $0.5647 \mathrm{mg} / \mathrm{L}$; the latter was approximately $0.25 \mathrm{mg} / \mathrm{L}$ higher. The results of the t-test verifying the differences between the groups $(\mathrm{t}=-60.914$ and $\mathrm{p}=.000)$ showed a significant difference at the level of $p<0.01$. The post-

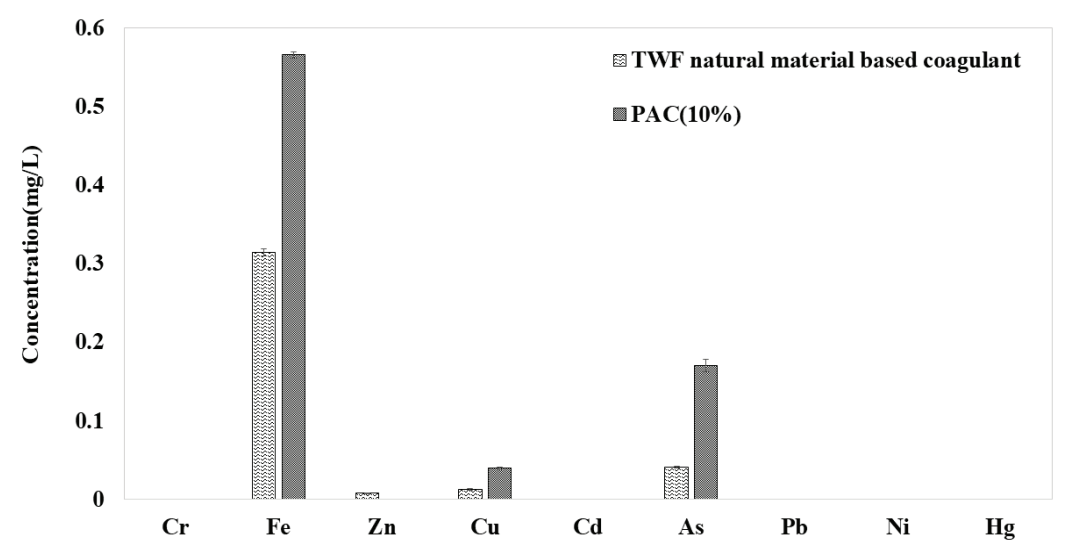

Fig. 1. Comparison of Heavy Metals Stability between Torrefied Wood Flour Natural Material based Coagulant and PAC (10\%). 
A Study on the Stability and Sludge Energy Efficiency Evaluation of Torrefied Wood Flour Natural Material Based Coagulant

test results for $\mathrm{Cu}$ with the different treatment agents showed that the average of the coagulant mixture was $0.012 \mathrm{mg} / \mathrm{L}$ and that of PAC (10\%) was $0.038 \mathrm{mg} / \mathrm{L}$; the latter was approximately $0.026 \mathrm{mg} / \mathrm{L}$ higher. The results of the t-test verifyingthe differences between the groups $(t=-15.922$ and $p=.000)$ revealed a significant difference at the level of $\mathrm{p}<0.01$. The post-test results for As showed that the average of the coagulant mixture was $0.0397 \mathrm{mg} / \mathrm{L}$, while that of PAC $(10 \%)$ was 0.17 $\mathrm{mg} / \mathrm{L}$; the latter was approximately $0.13 \mathrm{mg} / \mathrm{L}$ higher. The results of the t-test verifying the differences between the groups $(\mathrm{t}=-22.316$ and $\mathrm{p}=.000)$ showed a significant difference at the level of $\mathrm{p}<0.01$. According to the previous research on the adsorption of torrefied wood powder (Yang et al., 2016), the adsorption performance of iodine depending on the carbonization temperature was $590 \mathrm{mg} /$, which was a half of the maximum activated carbon. Therefore, the reason behind merely adding torrefied wood powder in the conventional PAC resulting in the reduced heavy metal contents in the water was because the powder adsorbed heavy metals in the coagulant mixture and lowered the contents. As for thecoagulant mixture, only a minimal amount of $\mathrm{Zn}(0.007 \mathrm{mg} / \mathrm{L})$ was detected, which was confirmed to be significantly lower than the criteria of $\mathrm{Zn}$ for drinking water $(3 \mathrm{mg} / \mathrm{L})$. Therefore, if water treatment is performed usingthe coagulant mixture developed in this study, the concentrations of heavy metals could be less than half of that of the commercially available coagulant and it will be environmentally stable.

\subsection{The results of sludge sedimentation evaluation}

To compare and analyze the sludge sedimentation rate between the coagulant mixture prepared in this study and PAC (10\%), the optimal amount, $10 \mathrm{ml}$, of the two was injected, and the sedimentation rates of sludge acquired from the mixing and coagulation processes were analyzed. Fig. 2 shows the sedimentation rates of sludge at a certain time interval.

The sedimentation of sludge is basically divided into 4 types: independent, coagulation, interfacial, and compression sedimentations. When a uniform concen-

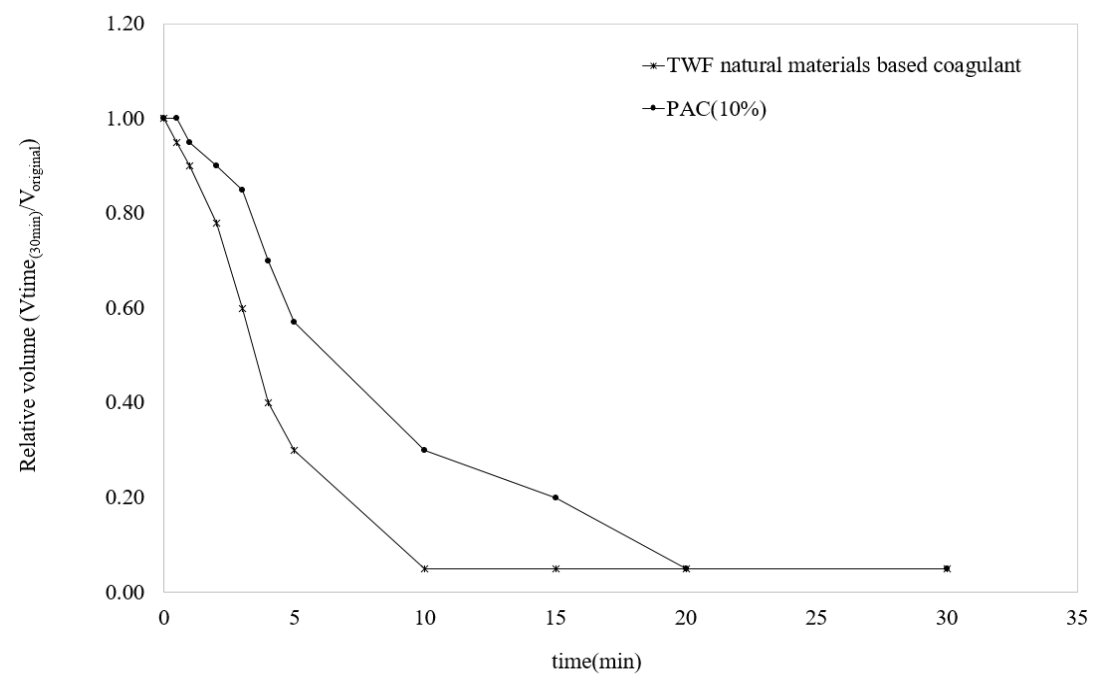

Fig. 2. Comparison of Sludge Sedimentation Rate between Torrefied Wood Flour Natural Material Based Coagulant and PAC (10\%). 
tration of suspended matter is put in a measuring cylinder, light particles dispersed in stages are settled independently just as independent particles or coagulating particles. If sedimentation continues, interfacial sedimentation occurs and a clear layer is formed on the top, creating a distinct boundary. Finally, compression sedimentation is caused by the weight of agglomerated particles continuously applied (Baik et al., 2014). As shown above in Fig. 2, the sedimentation rate of the coagulant mixture within the first 5 minutes was approximately twice the conventional coagulant, PAC $(10 \%)$. After approximately 10 minutes, the sedimentation of the coagulant mixture was almost completed, while the sedimentation of PAC (10\%) took approximately 20 minutes for completion. The comparison of the slopes of the graph indicates that the sedimentation rate of the coagulant mixture is higher than that of PAC (10\%). The faster sedimentation is considered to be because contaminants in the water cling together centering on torrefied wood powder of $75 \mu \mathrm{m}$ or less, which was added to the coagulant mixture, forming larger-sized flocs than when only PAC is added.

\subsection{The results of the evaluations of sludge heating values}

To evaluate the possibility of reuse of the coagulant mixture by comparing and analyzing its sludge heating value, the optimal amount $(10 \mathrm{ml})$ of the coagulant mixture and PAC (10\%) was injected, and the heating value of formed sewage sludge was measured. The water content of sewage sludge, which was generated after the jar test with effluent from a primary sedimentation tank, was approximately $90 \%$. This was dried in a drying oven at $105{ }^{\circ} \mathrm{C}$ to reduce the water content to $10 \%$ or lower, and the heating value was measured. Fig. 3 shows the results of the dry-basis heating value of the sewage sludge.

As a result of the post-test of the higher heating values based on different treatment agents, the average of the coagulant mixture was $3,656 \mathrm{kcal} / \mathrm{kg}$, while that of PAC $(10 \%)$ was $3,428 \mathrm{kcal} / \mathrm{kg}$; the PAC group showed approximately $227 \mathrm{kcal} / \mathrm{kg}$ lower result. The t-test verifying the difference between the two groups $(t=7.247$ and $p=0.002)$ showed that there was a significant difference at the level of $\mathrm{p}<0.01$.

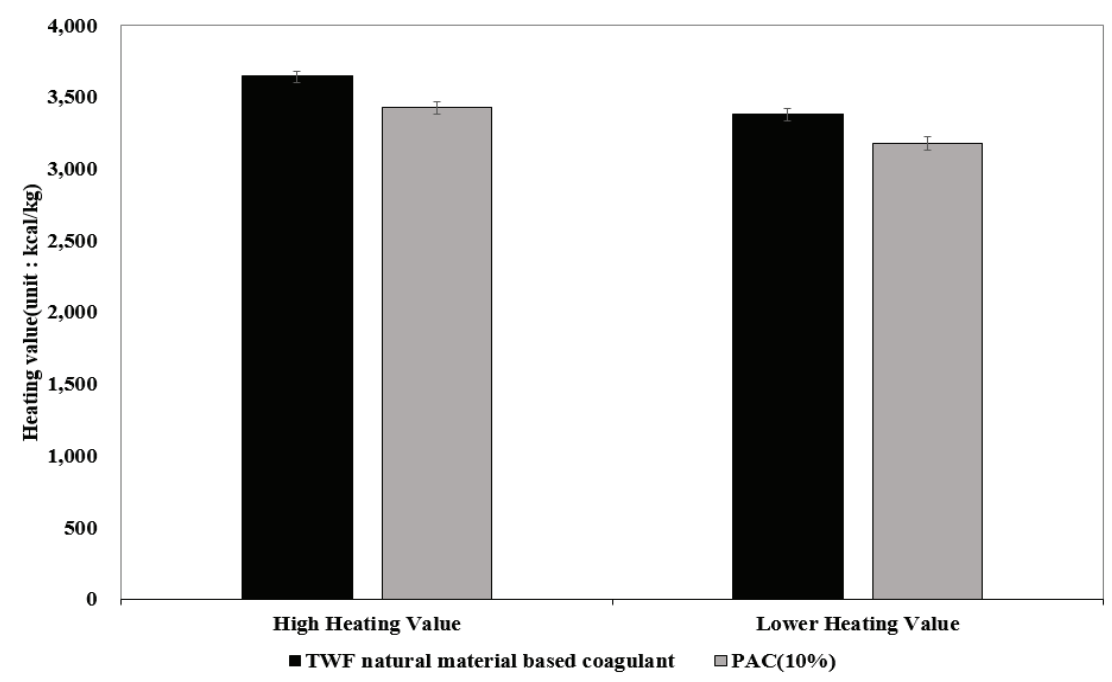

Fig. 3. Comparison of sludge calorific value between Torrefied Wood Flour Natural Material based Coagulant and PAC (10\%). 


\section{A Study on the Stability and Sludge Energy Efficiency Evaluation of Torrefied Wood Flour Natural Material Based Coagulant}

Before analyzing the heating values of the coagulant mixture and PAC (10\%), it is essential to perform a drying process to achieve the water content of less than $10 \%$. During the same drying process, the coagulant mixture containing torrefied wood powder took less drying time than PAC (10\%). The drying process is necessary, and it should satisfy the condition of more than $3,000 \mathrm{kcal} / \mathrm{kg}$ to be used as auxiliary fuel at thermal power plants. The dry-basis lower heating value of sewage sludge produced by injecting the coagulant mixture was $3,378 \mathrm{kcal} / \mathrm{kg}$, and that of sewage sludge produced by PAC (10\%) was $3,171 \mathrm{kcal} / \mathrm{kg}$; although both coagulants satisfied the requirements of the auxiliary fuel, the lower heating value of the coagulant mixture was revealed as higher by approximately 200 $\mathrm{kcal} / \mathrm{kg}$.

As a result, it was confirmed that the heating value of sewage sludge generated by the coagulant mixture developed in this study is approximately $200 \mathrm{kal} / \mathrm{kg}$ higher than that of the conventional coagulant. Thus, the coagulant mixture can produce sludge with higher heating values compared to that of the commercially available coagulant, PAC (10\%), and the possibility of achieving its stable utilization for energy reduction as an auxiliary fuel is confirmed.

\section{CONCLUSION}

This study used the commercially available coagulant, PAC (10\%), and coagulant mixture of torrefied wood powder and natural materials for water treatment and compared and analyzed the heavy metals in treated water to evaluate the stability against the heavy metals, and analyzed the sedimentation and heating values of sludge generated after the injection of the coagulants. As a result, the following conclusions were drawn:

1) The analysis of heavy metals from the coagulant mixture and PAC (10\%) revealed that the amounts of $\mathrm{Fe}, \mathrm{Cu}$, and $\mathrm{As}$ detected from PAC (10\%) were more than double compared to the coagulant mixture.

2) The analysis of the sludge sedimentation rates of the coagulant mixture and PAC $(10 \%)$ revealed that the rate of the coagulant mixture was higher than the conventional coagulant, PAC (10\%), within the first five minutes, and the sedimentation is completed for coagulant mixture in 10 minutes, while it took 20 minutes for PAC (10\%). The sedimentation rate of the coagulant mixture was faster than that of PAC $(10 \%)$.

3) The dry-basis lower heating value of sewage sludge produced by injecting the coagulant mixture was $3,378 \mathrm{kcal} / \mathrm{kg}$, and that of sewage sludge produced due to PAC (10\%) was $3,171 \mathrm{kcal} / \mathrm{kg}$; both coagulants met the requirements to be used as auxiliary fuel at thermal power plants.

In conclusion, it was revealed through the lab scale results that using the coagulant mixture prepared with torrefied wood powder in this study for water treatment in mixing and coagulation processes can result in better stability against heavy metals, faster sedimentation in sedimentation tanks, shorter sewage process time, and approximately $200 \mathrm{kal} / \mathrm{kg}$ higher heating value compared to the conventional coagulant, PAC (10\%). Going forward, it is necessary to conduct additional empirical studies on the application of the coagulant mixture in actual sewage treatment plants.

\section{ACKNOWLEDGMENT}

This work was supported by the National Research Foundation of Korea(NRF) grant funded by the Korea government (MSIT) (No. NRF-2017R1D1A1A 02019241). 


\section{REFERENCES}

Baik, S.J., Jo, J.M., Song, H.W., Han, I.S. 2014. Variation of sedimentation and dewaterability characteristics of sewage sludge under various coagulants. Journal of Korean Society on Water Environment 30(3): 311-318.

Chio, D.H., Kim, T.D., Park, J.W. 2016. Case study of sewage sludge treatment processes for resource recovery. Journal of the Korean Society of Urban Environmental 16(4): 399-406.

Gong, S.H., Ahn, B.J., Lee, S.M., Lee, J.J., Lee, Y.K, Lee, J.W. 2016. Thermal degradation behavior of biomass depending on torrefaction temperatures and heating rates. Journal of the Korean Wood Science and Technology 44(5): 685-694.

Han, G.H., Lee, S.Y., Lee, E.S., Kim, J.H., Cho, S.J., Kim, W.H., Seo, Y.C. 2019. Studies on characteristics of pyrolysis and char for efficient recycling of sewage sludge. Proceedings of the 2019 Spring Conference of the Korea Society of Waste Management.

Hwang, H.W., Choi, J.W. 2018. Preparation of nanoporous activated carbon with sulfuric acid lignin and its application as a biosorbent. Journal of the Korean Wood Science and Technology 46(1):17-28.

Korean Statistical Information Service(KOSIS). 2017. Swage statistics.

Lee, C.G., Kang, S.G. 2015. A study on fuel characteristics of mixtures using torreffied wood powder and waste activated carbon. Journal of Korean Society on Water Environment 43(1): 135-143.

Lee, G.J. 2004. A study on the alternatives for treating gludge generated from wonju sewage treatment plant. Master`s Thesis, Yonsei University, Korea. Ministry of Environment. 2017. A study on the revision of the water pollution standard method. ES $04400.1 \mathrm{c}$

Ministry of Environment. 2017. Current Status and Prospect of Coagulants and Flocculants for Water Treatment. KONETIC REPORT.

Nam, J.B., Oh, G.H., Yang, S.M., Lee, S.E., Kang, S.G. 2018. Evaluation of antioxidant activities of water extract from microwave torrefied oak wood. Journal of the Korean Wood Science and Technology 46(2): 178-188.

Park, S.E. 2009. Water Treatment Coagulant Market Trend. KONETIC REPORT.

So, S.H., Lee, B.H., Park, J.H., Cha, H.Y., Kim, H.S., Song, K.G. 2018. Improvement of dewaterability and settleability of sewage sludge using coagulation sludge. Journal of the Korean Society of Water and Wastewater 32(2): 89-96.

Yang, S.M., Nam, J.B., Oh, G.H., Kang, S.G. 2017. A study on the combustion characteristics of torrefied fuel by superheated steam treatment. Proceeding of the Korea Wood Science and Technology pp.41.

Yang, S.M., Lee, S.E., Park, H.K., Kang, S.G. 2019. A study on the impacts of paste type torrefied wood flour coagulants on water ecosystem. Journal of the Korean Wood Science Technology 47(6): 709-720.

Yang, S.M., Lee, H.J., Choi, C., Kim, H.J., Lee, W.J., Kang, S.G. 2016. Study on adsorption performance of surface modified torrefied wood flour using cationic PAM. Journal of Korea TAPPI 48(6): 271-276.

Yeon, J.M. Jeon, T.W., Kang, Y.Y., Jeon, M.J., Shin, S.K., Kim, Y.J., Jang, M.J. 2016. Study on heavy metals characteristics for recycling of wastewater treatment sludge. Journal of Korea Society of Waste Management 33(4): 338-346. 
A Study on the Stability and Sludge Energy Efficiency Evaluation of Torrefied Wood Flour Natural Material Based Coagulant

\title{
APPENDIX
}

\author{
(Korean Version)
}

\section{반탄화목분 천연재료 혼합응집제의 안정성 및 슬러지 에너지화 가능성 평가에 관한 연구}

\begin{abstract}
초록 : 하수처리장은 도시를 구성하는 사회기반시설물로 2017년 하수도 통계 기준 국내 하수도 보급률은 $94 \%$ 에 달하고 있다. 국내 하수처리장에서 PAC(Poly Aluminum Chloride)의 사용량이 58\%를 차지하고 있으나 PAC의 경우 품질기준상 불순물(중금속) 함량이 높음에도 불구하고, 기준 강화나 기술적 품질개선이 제대로 이루어지지 않아 응집제 과다 주입 시 2차 오염문제가 대두되고 있다. 또한, 약품사용량이 증가함에 따라 2017년 기준 연간 하수슬러지 발생량과 슬러지 재이용의 필요성 또한 증대되고 있다. 이에 본 연구에서는 반탄화목분 천연재료 혼합응집제를 이용한 수처리 시 혼합응집제 주입에 따른 중금속류에 대한 안정성을 평가하고, 하수슬러지의 침강성 및 하수슬러지 발열량 평가를 통해 슬러지 재이용의 가능성을 검증하고자 한다. 반탄화목분 천연재료 혼합응집제와 $\mathrm{PAC}(10 \%)$ 의 중금속류 $(\mathrm{Cr}, \mathrm{Fe}, \mathrm{Zn}, \mathrm{Cu}, \mathrm{Cd}, \mathrm{As}, \mathrm{Pb}, \mathrm{Ni})$ 분석 결과 $\mathrm{Cr}$, $\mathrm{Cd}, \mathrm{Pb}, \mathrm{Ni}, \mathrm{Hg}$ 의 경우 검출되지 않았으며, $\mathrm{Zn}$ 의 경우 반탄화목분 천연재료 혼합응집제에서 먹는물 수질기준에서 고시한 $\mathrm{Zn}$ 의 농도가 $3 \mathrm{mg} / \mathrm{L}$ 인 것에 비해 $0.007 \mathrm{mg} / \mathrm{L}$ 로 극소량만 검출되었다. $\mathrm{Fe}, \mathrm{Cu}, \mathrm{As}$ 의 경우 $\mathrm{PAC}(10 \%)$ 를 주입한 경우가 반탄화목 분 천연재료 혼합응집제 보다 최대 2 배 이상 검출되는 것으로 나타났다. 또한, 슬러지 침강성 분석 결과 반탄화목분 천연재료 혼합응집제가 기존 응집제인 $\mathrm{PAC}(10 \%)$ 에 비해 최대 2 배 빠르게 침강하는 것으로 반탄화목분 혼합응집제의 침강성이 $\mathrm{PAC}(10 \%)$ 보다 우수한 것으로 나타났다. 반탄화목분 천연재료 혼합응집제를 주입하여 발생된 하수슬러지의 건조기준 저위발열 량은 $3,378 \mathrm{kcal} / \mathrm{kg}$ 이며, $\mathrm{PAC}(10 \%)$ 응집제를 주입하여 발생된 하수슬러지의 건조기준 저위발열량은 $3,171 \mathrm{kcal} / \mathrm{kg}$ 으로 두 응집제 모두 화력발전소의 보조연료 구비조건을 만족하였으나, 본 연구에서 개발한 반탄화목분 천연재료 혼합응집제를 사용할 경우 기존의 응집제보다 $200 \mathrm{kal} / \mathrm{kg}$ 정도 높은 슬러지 발열량을 확보할 수 있음을 확인하였다. 따라서, 반탄화목분 혼합응집제를 이용하여 수처리를 수행할 경우 기존의 응집제인 $\mathrm{PAC}(10 \%)$ 보다 중금속류에 대해 안정적이며, 우수한 슬러지 침강성과 높은 발열량을 갖는 슬러지를 생성하여 환경적으로 안정적이며, 효율적인 활용이 가능할 것으로 판단된다.
\end{abstract}

\section{1. 서 론}

하수처리장은 경제발전에 따른 도시화 현상에 따라 도시를 구성하는 사회기반시설물로 2017년 하수도 통계 기준 국내 하수도 보급률은 $94 \%$ 로 국내 하수처리장은 4,072 개소에 달하고 있다. 경제성장에 따라 발생되는 지구온난화와 이상기후 현상으로 매년 수질관리의 중요성과 이에 따른 관리비용이 증가되고 있다(Hwang and Choi, 2018). 국내 하수처리장에서는 안정적인 수질 개선을 위해 고도처리시설의 도입과 방류수질 기준 강화 및 오염 총량제를 시행하였다. 합류식 하수관거 형태에서 분류식 하수관거의 하수관로 개량사업이 시행됨에 따라 유입 하수량은 줄어들었으나, 오염부하량 증가로 실제 투입되는 약품의 사용량 이 증가되고 있다(MOE, 2017). 국내 하수처리장에서 사용되는 응집제는 무기고분자 응집제인 PAC(Poly Aluminum Chloride) 의 사용량이 $58 \%$ 를 차지하고 있다. 사용되는 PAC(Poly Aluminum Chloride)의 경우 품질기준상 불순물(중금속) 함량이 매우 높음에도 불구하고, 기준 강화나 기술적 차원에서의 품질개선이 제대로 이루어지지 않아 응집제 과다 주입 시 중금속류에 대한 2차 오염문제가 대두되고 있다(Park, 2009). 약품사용량증가에 따라 2017년 기준 연간 하수슬러지 발생량은 $11,415 \mathrm{~m}^{3} / \mathrm{d}$ 로 하수처리 공정에서 발생되는 연간 하수슬러지는 점차 증가(So et al., 2018)되며 하수슬러지 재이용에 대한 방안이 추가적으로 모색되고 있으며 현재 보조연료, 퇴비로 사용되며 점차 하수슬러지의 재이용율 또한 증가되고 있다.

그러나 런던협약에 의거하여 하수슬러지의 해양배출이 전면적으로 금지됨에 따라 지상에서의 하수슬러지 매립, 재활용 및 전처리를 통해 최종 처분되고 있다(Han et al., 2019). 또한, 최근 매립지내에서도 하수슬러지의 반입을 금지하고 폐기물관리법에 명시하고 있다는 점에서 매립처리에 대한 한계성이 나타나고 있다. 이로 인해 하수슬러지의 효율적인 처리에 대해 새로운 대책이 요구되고 있다. 이에 다양한 전처리 기술을 이용한 하수슬러지 감량화 또는 발생되는 슬러지의 효율적인 자원화와 에너지화의 필요성이 제기되고 있다(Choi et al., 2016). 하수슬러지의 재활용률을 높이기 위해 현재 건조, 소각, 탄화 등과 같은 열적 처리과정을 거쳐 화력발전소 보조연료로 재이용, 슬러지 퇴비화, 부숙 공정을 통한 비료, 녹생토 및 복토재로의 재활용 및 시멘트 제조의 부원료 등으로 사용되고 있다(Yeon et al., 2016). 그러나 퇴비화의 경우 처리시간이 매우 길어 부지 
또는 장치의 용량이 커져 비용 문제가 발생하는 점이 있으며, 비료화의 경우 슬러지내의 중금속이 재자원화에 있어 환경적 안전성 문제가 제기되고 있다(Lee, 2004).

지구온난화에 따른 수질 오염의 문제뿐만 아니라 국내 산림환경에도 병충해의 유입 및 확산에 대한 문제도 발생하고 있다. 병충해피해목의 경우 훈증 및 소각처리 등 다양한 방제작업 및 계획이 추진되어 있지만 확실한 치료법이 없어 산림자원에 경제적 손실을 초래하고 있다. 이와 같이 병충해피해목 및 솦가꾸기 부산물 등 미이용되는 국내 산림자원에 고부가가치화 기술을 접목하여 국내 산림자원의 이용 확대를 위한 방안 모색이 필요하다(Lee et al., 2015). 이에 반탄화목분을 재료로 하여 추출물의 항산화 성분 분석, 농부산물, 하수슬러지 등 다양한 바이오매스에 대한 반탄화 연구가 진행되고 있다(Nam et al., 2018; Gong et al., 2016). 따라서 본 연구에서는 반탄화목분 천연재료 혼합응집제를 이용한 수처리 시 혼합응집제 주입에 따른 중금속류 분석과 PAC 주입에 따른 중금속류를 비교·분석하여 중금속류에 대한 안정성을 평가하고, 하수처리장에서 응집제 주입 후 혼화응집 처리 시 발생되는 슬러지의 침강성 및 하수슬러지 발열량 평가를 통해 환경적 측면에서의 안정성과 화력발전 소의 보조연료로써의 자원 재이용의 가능성을 검증하고자 한다.

\section{2. 재료 및 방법}

2.1. 반탄화목분 천연재료 혼합응집제 제조

본 연구에서 반탄화목분 천연재료 혼합응집제 제조에 있어 반탄화목분은 과열증기처리 조건에 따라 반탄화목분의 음전하 조절 및 액체 흡착성능을 나타낸다는 선행연구(Yang et al., 2016)와 동일한 반탄화 목재칩 제조 조건을 선정하였다. 반탄화 목재칩 제조를 위하여 함수율 $12 \%$ 의 참나무 목재칩을 사용하였다. 구미소재의 $\mathrm{S}$ 사에 의뢰하여 과열증기처리장치를 이용하여 $250{ }^{\circ} \mathrm{C}$ 에서 25 분간 처리된 반탄화목재칩을 분양받아 실험실용 소형 고속분쇄기를 이용하여 분쇄 및 75-106 um 크기로 분급된 반탄화목분을 사용하였다(Yang et al., 2017). 또한, 반탄화목분 천연재료 혼합응집제 제조 시 무기 고분자 응집제인 $\mathrm{PAC}$ 를 사용하였는데, $\mathrm{PAC}$ 는 양이온성 전하를 가지고 있는 염기성 다핵착이온의 구조를 갖는 무기고분자 화합물로 강력한 응집작용을 나타내는 수처리용 응집제이다. $\mathrm{PAC}$ 는 염산과 알루미늄으로 만든 폴리머 계열의 응집제로 본 연구에서는 무색 내지 담황색의 투명한 액상 $\mathrm{PAC}$ 를 사용하였다. 국내 하수처리장에서 보편적으로 사용되는 $\mathrm{PAC}(10 \%)$ 의 경우 산화알루미늄 $\left(\mathrm{Al}_{2} \mathrm{O}_{3}\right)$ 농도가 $10 \%$ 인 것으로 본 연구에서는 이러한 산화알루미늄 $\left(\mathrm{Al}_{2} \mathrm{O}_{3}\right)$ 농도를 $7 \%$ 로 저감시켜 $\mathrm{PAC}(7 \%)$ 를 제조하였다. 최종적으로 본 연구에서는 기 수행된 반탄화목분 천연재료 혼합응집제의 최적 혼합비율 연구(Yang et al., 2019)에서 도출된 혼합비율에 따라 제조된 PAC(7\%) $500 \mathrm{ml}$ 에 반탄화목분 $5 \mathrm{~g}$ 첨가하여 $800 \mathrm{rpm}$ 에서 약 5 시간 교반을 통해 제조하여 본 실험의 공시재료로 사용하였다.

\subsection{Jar test}

반탄화분말 천연재료 혼합응집제의 안정성, 슬러지 침강속도 및 슬러지 발열량 평가를 위해 수중 유기물질 함유량이 높은 대전하수처리장 1 차침전지 유출수를 대상으로 채수하여 사용하였다. 혼합응집제의 안정성 평가를 위해 혼합응집제 조건에 따라 Jar test를 수행하였고, Jar test 운전 조건은 급속교반 $140 \mathrm{rpm} 2 \mathrm{~min}$, 완속교반 $40 \mathrm{rpm} 20 \mathrm{~min}$, 침전시간 $30 \mathrm{~min}$ 을 거쳐 상등액을 채취하였다. 상등액 채취 시 $45 \mu \mathrm{m}$ 공극을 가진 실린지 필터를 통해 여과시킨 후 분석시료로 사용하였다. 분석항목은 ‘수질오염공정시험기준(제 2017-4호)」 중금속류 항목에 해당하는 $\mathrm{Cr}, \mathrm{Fe}, \mathrm{Zn}, \mathrm{Cu}, \mathrm{Cd}, \mathrm{As}, \mathrm{Pb}, \mathrm{Ni}, \mathrm{Hg}$ 에 대해 측정하였으며, Jar test 후 발생되는 슬러지의 침강속도와 발열량에 대해 분석하였다.

\section{3. 중금속류 분석}

본 연구에서 제조한 혼합응집제의 안정성 분석을 위해 중금속류 분석을 수행하고자 하며, 분석대상항목은 「수질오염공정시험 기준(제 2017-4호)」중금속류 항목에 해당하는 $\mathrm{Cr}, \mathrm{Fe}, \mathrm{Zn}, \mathrm{Cu}, \mathrm{Cd}, \mathrm{As}, \mathrm{Pb}, \mathrm{Ni}, \mathrm{Hg}$ 이다. 중금속류 분석은 FITI 시험연구원에 시료분석 의뢰하였으며, 분광광도법, 발광분광법, 질량분석법 기기분석에 의해 3 회 반복 수행하였다.

\section{4. 슬러지 침강성 분석}

본 연구에서 제조한 혼합응집제를 이용한 수중 오염물질의 혼화응집 공정을 거쳐 침전공정에서 생성된 슬러지의 침강성 실험은 메스실린더를 이용하여 $30 \mathrm{~min}$ 동안 1-10 $\mathrm{min}$ 간격마다 floc의 침강부피를 측정하여 일정 시간 경과에 따른 슬러지 침강부피를 측정하는 방법으로 구성하였다. 슬러지 침강성 분석 실험 시 Jar test 이후 생성된 floc이 깨지지 않도록 1,000 $\mathrm{ml}$ 메스실린더에 옮겨서 수행하였으며, 기존 수처리제와의 슬러지 침강성 비교분석을 위해 본 연구에서 개발한 반탄화목분 
A Study on the Stability and Sludge Energy Efficiency Evaluation of Torrefied Wood Flour Natural Material Based Coagulant

천연재료 혼합응집제와 $\mathrm{PAC}(10 \%)$ 최적 주입량을 기준으로 슬러지 침강성을 비교하는 목적으로 실험을 수행하였다.

\section{5. 슬러지 발열량 분석}

하수슬러지의 보조연료로의 재이용 시 화력발전소 보조연료 구비조건인 $3,000 \mathrm{kcal} / \mathrm{kg}$ 이상을 만족하여야 한다. 하수슬러지 의 발열량을 측정하기 위해 Jar test 후 침전된 하수슬러지를 채취한 후 함수율이 $10 \%$ 이하가 되도록 $105{ }^{\circ} \mathrm{C}$ 건조오븐에서 건조하였다. 전건시험편 기준인 고위발열량(Higher Heating Values)을 측정하기 위해 봄배형 열량계(Bomb Calorimeter, SDC series Calorimeter, YEONJIN S-TECH INC.)를 이용하여 고위발열량 $(\mathrm{kcal} / \mathrm{kg})$ 을 5 반복 측정하였으며, 고위발열량 측정 후, 저위 발열량을 계산하여 산출하였다.

\section{3. 결과 및 고찰}

\section{1. 중금속류 분석 결과}

DJ하수처리장 1 차침전지 유출부에서 채취한 하수를 이용하여 Jar test를 수행하였으며, 기 수행된 연구로 도출된 최적 응집제 주입량으로 각각의 응집제 $10 \mathrm{ml} / \mathrm{L}$ 를 주입한 후 상등액을 채취하여 중금속류 $(\mathrm{Cr}, \mathrm{Fe}, \mathrm{Zn}, \mathrm{Cu}, \mathrm{Cd}, \mathrm{As}, \mathrm{Pb}, \mathrm{Ni})$ 항목 분석을 수행하였으며, 분석결과는 다음 Fig. 1에 나타내었다.

동일 응집제 주입량에서 $\mathrm{PAC}(10 \%)$ 와 반탄화목분 천연재료 혼합응집제를 이용하여 혼화응집·침전 공정을 수행한 결과 금속류 중 $\mathrm{Cr}, \mathrm{Cd}, \mathrm{Pb}, \mathrm{Ni}, \mathrm{Hg}$ 의 경우 검출되지 않았으며, $\mathrm{PAC}(10 \%)$ 를 이용하여 응집처리를 수행한 처리수에서 더 높은 농도의 $\mathrm{Fe}, \mathrm{Cu}, \mathrm{As}$ 가 발생되는 것을 알 수 있었다. 처리제 종류에 따라 $\mathrm{Fe}$ 의 사후검사 결과 TWF natural Material based Coagulant의 평균은 $0.3143 \mathrm{mg} / \mathrm{L}, \mathrm{PAC}(10 \%)$ 의 평균은 $0.5647 \mathrm{mg} / \mathrm{L}$ 로 PAC 집단이 약 $0.25 \mathrm{mg} / \mathrm{L}$ 더 높게 나타났으며, 두 집단 간 차이를 검증하기 위하여 실시된 t-test 결과 $\mathrm{t}=-60.914$ 이고, $\mathrm{p}=.000$ 이므로 $\mathrm{p}<0.01$ 수준에서 유의미한 차이가 있는 것으로 나타났다. 처리제 종류 간 $\mathrm{Cu}$ 의 사후검사 결과 TWF natural Material based Coagulant의 평균은 $0.012 \mathrm{mg} / \mathrm{L}, \mathrm{PAC}(10 \%)$ 의 평균은 $0.038 \mathrm{mg} / \mathrm{L}$ 로 $\mathrm{PAC}$ 집단이 약 $0.026 \mathrm{mg} / \mathrm{L}$ 더 높게 나타났으며, 두 집단 간 차이를 검증하기 위하여 실시된 $\mathrm{t}$-test 결과 $\mathrm{t}=-15.922$ 이고, $\mathrm{p}=.000$ 이므로 $\mathrm{p}<0.01$ 수준에서 유의미한 차이가 있는 것으로 나타났다. As 사후검정 결과 TWF natural Material based Coagulant의 평균은 $0.0397 \mathrm{mg} / \mathrm{L}, \mathrm{PAC}(10 \%)$ 의 평균은 $0.17 \mathrm{mg} / \mathrm{L}$ 로 PAC 집단이 약 $0.13 \mathrm{mg} / \mathrm{L}$ 더 높게 나타났으며, 두 집단 간 차이를 검증하기 위하여 실시된 $\mathrm{t}$-test 결과 $\mathrm{t}=-22.316$ 이고, $\mathrm{p}=.000$ 이므로 $\mathrm{p}<0.01$ 수준에서 유의미한 차이가 있는 것으로 나타났다. 이는 기존의 PAC에 반탄화목분 첨가만으로 수중의 중금속 함량 저감 효과가 나타난 이유는 반탄화목분 흡착성능에 관한 선행연구(Yang et al., 2016)에 따르면 탄화온도에 따라 요오드 흡착성능이 최대 활성탄의 절반 수준인 $590 \mathrm{mg}$ 의 흡착성능의 결과를 토대로 PAC에 반탄화목분 혼합 시 혼합응집제 내에 존재하는 중금속을 반탄화목분이 흡착하여 낮은 중금속 함량을 나타낸 것으로 판단된다. 반탄화목분 천연재료 혼합응집제의 경우 $\mathrm{Zn}$ 이 $0.007 \mathrm{mg} / \mathrm{L}$ 의 극소량의 농도만 검출되는 것을 확인하였는데, 해당 농도는 먹는물 수질기준에 의거한 $\mathrm{Zn}$ 농도가 $3 \mathrm{mg} / \mathrm{L}$ 인 것에 비해 매우 낮은 농도인 것으로 나타났다. 이에 본 연구에서 개발한 반탄화목분 천연재료 혼합응집제를 사용하여 수처리를 수행할 경우 시판 응집제 보다 중금속류에 대해 2 배 이상 낮은 농도로 보다 환경적으로 안정적인 수처리를 수행할 수 있다고 판단된다.

\section{2. 슬러지 침강성 평가 결과}

본 연구에서 제조한 반탄화목분 천연재료 혼합 응집제의 슬러지 침강 속도를 비교 분석하기 위해 혼합응집제와 $\mathrm{PAC}(10 \%)$ 의 최적 주입량인 $10 \mathrm{ml}$ 를 주입한 후 혼화응집 공정을 통해 형성된 슬러지의 침강 속도를 분석하였다. 다음 Fig. 2는 생성된 슬러지의 침강 속도 분석은 일정시간 간격에 따른 침강속도를 측정한 것이다.

슬러지의 침강은 기본적으로 4 가지 형태로 독립침강, 응집침강, 계면침강, 압밀침강으로 구분된다. 균일한 농도의 부유물질을 메스실린더에 넣었을 경우, 단계적으로 분산되어 있는 가벼운 입자들은 독립입자나 응결성 입자와 같이 독립적으로 침전되며, 침전이 지속되면 계면침전과 상층부에 맑은 층이 형성되어 뚜렷한 경계면이 형성되고, 최종적으로 압밀침강은 연속적으로 가해지는 응집 입자들의 무게에 의해 발생된다(Baik et al., 2014). 위의 Fig. 2에 나타난 바와 같이 초기 $5 \mathrm{~min}$ 이내의 침강속도의 경우 기존 응집제인 $\mathrm{PAC}(10 \%)$ 에 비해 반탄화목분 천연재료 혼합응집제가 최대 2 배 정도 빠른 속도로 침강하는 것으로 나타났 으며, 침전시간이 $10 \mathrm{~min}$ 정도 경과되었을 경우 혼합응집제의 경우 침강이 거의 완료되었으며, $\mathrm{PAC}(10 \%)$ 의 경우 $20 \mathrm{~min}$ 정도 경과 후에 침강이 거의 완료되었음을 알 수 있었다. 또한, 그래프의 기울기를 비교하면, 반탄화목분 혼합응집제의 침강속도 가 $\mathrm{PAC}(10 \%)$ 보다 우수한 것으로 나타났다. 이는 혼합응집제에 첨가된 $75 \mathrm{um}$ 이하의 반탄화 목분을 중심으로 수중 오염물질이 응집되어 floc 크기가 PAC 만을 첨가할 경우 보다 크므로 침강속도가 빠른 것으로 판단된다. 


\section{Hae Keum PARK $\cdot$ Seog Goo KANG}

\section{3. 슬러지 발열량 평가 결과}

반탄화목분 천연재료 혼합 응집제의 슬러지 발열량을 비교 분석하여 재이용에 관한 가능성을 평가하기 위해 혼합응집제와 $\mathrm{PAC}(10 \%)$ 의 최적 주입량인 $10 \mathrm{ml}$ 를 주입한 후 형성된 하수 슬러지를 대상으로 발열량을 측정하였다. 하수처리장 1 차 침전지 유출수를 대상으로 Jar test를 수행한 후 발생된 하수슬러지의 수분함량은 대략 $90 \%$ 전후를 보이고 있으며, 이를 $105{ }^{\circ} \mathrm{C}$ 건조 오븐에서 함수율 $10 \%$ 이하로 건조시켜 열량을 측정하였다. 다음 Fig. 3 은 건조기준 하수슬러지의 발열량 측정 결과이다.

처리제 종류에 따라 고위발열량의 사후검사 결과 TWF natural Material based Coagulant의 평균은 3,656 kcal $/ \mathrm{kg}, \mathrm{PAC}(10 \%)$ 의 평균은 $3,428 \mathrm{kcal} / \mathrm{kg}$ 로 PAC 집단이 약 $227 \mathrm{kcal} / \mathrm{kg}$ 낮게 나타났으며, 두 집단 간 차이를 검증하기 위하여 실시된 t-test 결과 $\mathrm{t}=7.247$ 이고, $\mathrm{p}=0.002$ 이므로 $\mathrm{p}<0.01$ 수준에서 유의미한 차이가 있는 것으로 나타났다.

혼합응집제와 $\mathrm{PAC}(10 \%)$ 의 발열량 분석에 앞서 수분함량을 $10 \%$ 이하로 건조 과정이 필수적이며, 동일 건조과정에서 반탄화 목분이 함유된 혼합응집제가 $\mathrm{PAC}(10 \%)$ 보다 건조 시간이 단축되었다. 수분함량 $10 \%$ 이하의 건조과정이 필요하며, 화력발전소 의 보조연료 구비조건은 $3,000 \mathrm{kcal} / \mathrm{kg}$ 이상을 만족하여야 한다. 반탄화목분을 혼합한 혼합응집제를 주입하여 발생된 하수슬러 지의 건조기준 저위발열량은 $3,378 \mathrm{kcal} / \mathrm{kg}$ 이며, $\mathrm{PAC}(10 \%)$ 응집제를 주입하여 발생된 하수슬러지의 건조기준 저위발열량은 $3,171 \mathrm{kcal} / \mathrm{kg}$ 으로 두 응집제 모두 화력발전소의 보조연료 구비조건을 만족하였으나, 반탄화목분 천연재료 혼합응집제의 저위발 열량이 약 $200 \mathrm{kcal} / \mathrm{kg}$ 정도 더 높게 나타났다.

이를 통해 본 연구에서 개발한 반탄화목분 천연재료 혼합응집제를 사용할 경우 기존의 응집제보다 $200 \mathrm{kal} / \mathrm{kg}$ 정도 높은 하수슬러지 발열량을 확보할 수 있음을 확인하였으며, 이에 시판 응집제인 $\mathrm{PAC}(10 \%)$ 보다 높은 발열량을 갖는 슬러지를 생성하 여 보조연료로써의 에너지 절감효과를 기대할 수 있는 안정적인 활용이 가능할 것으로 판단된다.

\section{4. 결 론}

본 연구에서는 시판 응집제인 $\mathrm{PAC}(10 \%)$ 와 반탄화목분 천연재료 혼합응집제를 이용한 수처리 시 처리수의 중금속류를 비교·분석하여 중금속류에 대한 안정성을 평가하고, 응집제 주입 후 발생되는 슬러지의 침강성 및 슬러지 발열량 분석을 수행하 였으며, 다음과 같은 결론을 도출하였다.

1) 반탄화목분 천연재료 혼합응집제와 $\mathrm{PAC}(10 \%)$ 의 중금속류 분석 결과 $\mathrm{Fe}, \mathrm{Cu}, \mathrm{As}$ 의 경우 $\mathrm{PAC}(10 \%)$ 를 주입한 경우 반탄화목분 천연재료 혼합응집제 보다 최대 2 배 이상 검출되었다.

2) 반탄화목분 천연재료 혼합응집제와 $\mathrm{PAC}(10 \%)$ 의 슬러지 침강속도 분석 결과 초기 5 분 이내의 침강속도의 경우 반탄화목분 천연재료 혼합응집제 > 기존 응집제인 $\mathrm{PAC}(10 \%), 10$ 분경과 혼합응집제의 경우 침강 완료, 20 분경과 $\mathrm{PAC}(10 \%)$ 침강 완료되었으며 반탄화목분 혼합응집제의 침강속도가 $\mathrm{PAC}(10 \%)$ 보다 우수한 결과를 나타냈다.

3) 반탄화목분 천연재료 혼합응집제를 주입하여 발생된 하수슬러지의 건조기준 저위발열량은 $3,378 \mathrm{kcal} / \mathrm{kg}$ 이며, $\mathrm{PAC}(10 \%)$ 응집제를 주입하여 발생된 하수슬러지의 건조기준 저위발열량은 $3,171 \mathrm{kcal} / \mathrm{kg}$ 으로 두 응집제 모두 화력발전소의 보조연 료 조건을 만족하였다.

따라서, 본 연구에서 개발한 반탄화목분 혼합응집제를 이용하여 혼화응집 공정의 수처리를 수행할 경우 기존의 응집제인 $\mathrm{PAC}(10 \%)$ 보다 중금속류 안정성확보, 침전지에서의 침강속도 확보로 하수처리 공정 시간 단축, $200 \mathrm{kal} / \mathrm{kg}$ 정도 높은 발열량을 확보할 수 있음을 Lab. scale의 결과를 통해 확인하였다. 실제 하수종말처리장에서의 혼합응집제 적용에 따른 추가적인 실증 연구가 필요할 것으로 판단되다. 